\title{
食卓の色彩が食物の印象に与える影響
}

\author{
豊満美峰子* ·松本仲子** \\ (女子栄養大学短期大学部*, 女子栄養大学**)
}

\section{The Influences of the Color of the Table on the Impressions of Foods}

\author{
Mioko Toyomitsu*, Nakako Matsumoto** \\ *Junior College of Kagawa Nutrition University, 3-24-3, Komagome, Toshima-ku,Tokyo, 170-8481 \\ ${ }^{* *}$ Kagawa Nutrition University, 3-9-21, Chiyoda, Sakado-shi, Saitama, 350-0288 \\ *テ170-8481 東京都豊島区駒込 3-24-3

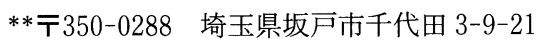

\begin{abstract}
The sense evaluation was done to examine the influences of the color of the table on the impression of foods. The background was changed by using a paper covers in eight different colors, i.e. yellow, orange, red, purple, blue, green, white and black. The evaluation was done using the SD method with 10 pair descriptions word. The results are as follows.

1. When orange was the background, the impression of the table was evaluated as "It seems to be favorable." "It seems to be delicious." "It seems to be nutritious." And when purple was the background, it showed a tendency to evaluate it as "like a bumpkin" "older for their age" "It isn't clean." "It seems to be nonnutritious." "It is vulgar." "It isn't beautiful.". No differences were hardly recognized between the colors except for orange and purple.
\end{abstract}

2. The main factors could not be determined in spite of using a factor analysis for the results of the SD method.

3 . A correlation was recognized between the preference for the colors and the impressions by the colors of the table. In other words, the impression of the food is influenced by one's favorite colors.

\section{1. 緒言}

食物の嗜好は，年齢・性別・地域その他種々の要因に よって左右されるが，これらは食物を摂取する人間側に 起因するものである。一方，嗜好に影響を及ぼす食物そ のものの要因としては，味・香り・テクスチャー・外観 などがあげられ，特に食物を口にする前に視覚的・嗅覚 的な刺激が認識される.とりわけ外観は嗜好に大きな影 響を及ぼす因子であるとされ，嗜好に関する研究報告で

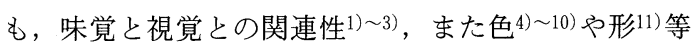
の外観のウェイトが大きいこと等が報告されている.

アメリカの色彩学者 F.Birren が「食欲を増進させる 色彩はオレンジ」という説12)を発表して以来, 食器や食 卓等においてオレンジを重用する傾向が見られるもの の, Birrenの実験対象は食堂の壁紙についての研究で あって, 食器や食卓についてのものではない. 食器・食 卓等についての報告 ${ }^{13)}$ はあまり多くはない。ここでは主 として食卓の色彩が食べ物の印象にどのように影響を及 
ぼすかを検討することにした．

\section{2. 実験方法}

\section{1）実験に採択した色彩}

8 色のラシャ紙を食卓上に敷いて食卓の色彩とした。 実験で採択した色彩は, 無彩色の白・黒, 有彩色加は 3 原色の赤・青・黄, 及びそれぞれの補色である緑・オ レンジ・紫の 8 色彩とし, 標準色彩図表 ${ }^{14)}$ とより同定し て, 表 1 に示した.

表 1 実験に用いた色彩のマンセル値

\begin{tabular}{c|c|c|c}
\hline & 色相 & 明度 & 彩度 \\
\hline 黄 & $5 \mathrm{Y}$ & 8 & 12 \\
オレンシ & $5 \mathrm{YR}$ & 7 & 10 \\
赤 & $10 \mathrm{RP}$ & 5 & 12 \\
紫 & $2.5 \mathrm{P}$ & 5 & 6 \\
青 & $5 \mathrm{~PB}$ & 5 & 8 \\
緑 & $7.5 \mathrm{G}$ & 5 & 8 \\
白 & & 10 & \\
黒 & & 2 & \\
\hline
\end{tabular}

\section{2 ) 実験場所·実験日時·実験対象者}

実験場所は, 埼玉県坂戸市に所在する大学寮のキャフ エテリアとし, 実験日時は, 12 月から 1 月にかけての 2 〜 3 日ずつ間隔をおいた 8 日間の朝食時とした. 8 日間 の室温はほほ11〜14度, 室内の照度は梥側の明るい場所 では晴天の日約1,050ルクス, 量りの日約680ルクスであ り, 奥側の暗い場所では晴天の日約680ルクス, 量りの 日480ルクスであった。照度は照度計 HIOKI JUX Hi TESTER3421 を使用し, 食事時間の15分前に測定 した.

実験対象者は女子栄盖大学在学の 18 歳〜20歳女性 96 名 であった.

\section{3) 実験方法}

ラシャ紙をキャフェテリアの空側 5 卓, 奥側 5 卓の計

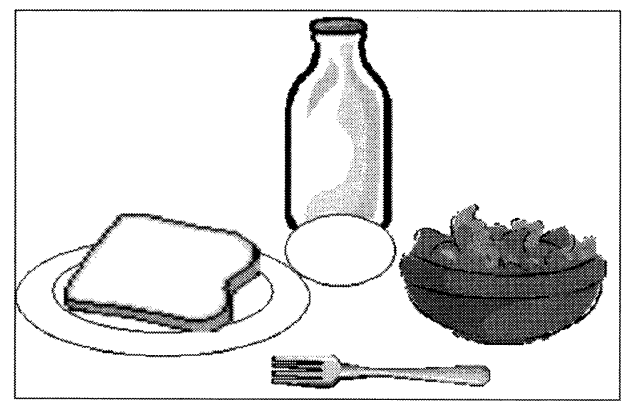

図 1 食器の配置図
10 食卓に敷き，上に透明のビニールクロスをかけてテー ブルクロスと見なすことにした．1日1色ずつ使用し， 8 日間で 8 色彩を実験した。色彩の使用順序はランダム に選択し, オレンジ・黒·青·赤・緑·白·紫・黄の順 に行った.

朝食時の献立は 8 日間ともパンに牛乳・グリーンサラ ダ・ゆで卵とし図1のように配置した。パンは白色の洋 皿, サラダは無色透明のガラス鉢, 牛乳は無色透明のび んのまま, 卵は殼つきのまま直接食卓に置いた、サラダ の食材は, レタス・きゅうりで緑色である。キャフェテ リアはセルフサービス方式のため, 牛乳・パン・フォー ク・卵はあらかじめセッティングしておき，サラダのみ 各自で配膳しパンの右側に置くよう指示した．1食卓に は10人ずつ着席し，着席後食卓上を見渡しながら質問に 答えた。座席は毎回同じ位置とした。

\section{4 ) 質問方法}

質問は SD 法により，調査票は表 2 に示した，評価項 目は，食卓を見たときのイメージとして想定される形容 語対を選んだ。「好き一嫌い」「おいしそう一まずそう」 「温かそう一冷たそう」「都会的な一田舎っぽい」「若々 しい一年寄りじみた」「涼しそうな一暑苦しそうな」「清 潔な一不潔な」「栄養がありそうな一なさそうな」「上品 な一下品な」「美しい一美しくない」の10項目である.

パン・牛乳・サラダの各々について, 各色彩を背景に したときの印象を食前に回答してもらった，得られた結 果は, 因子分析により解析した.

表 2 質問票(1)

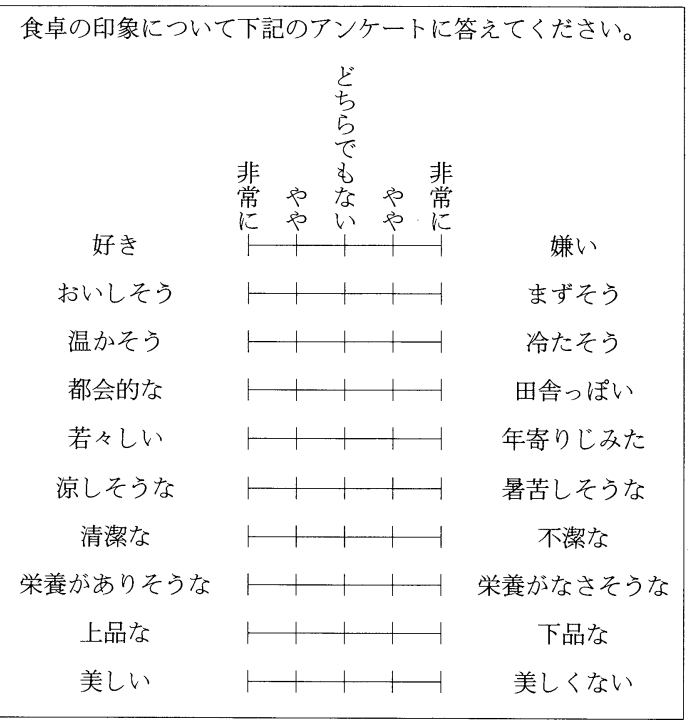

(19) 173 
表 3 質問票(2)

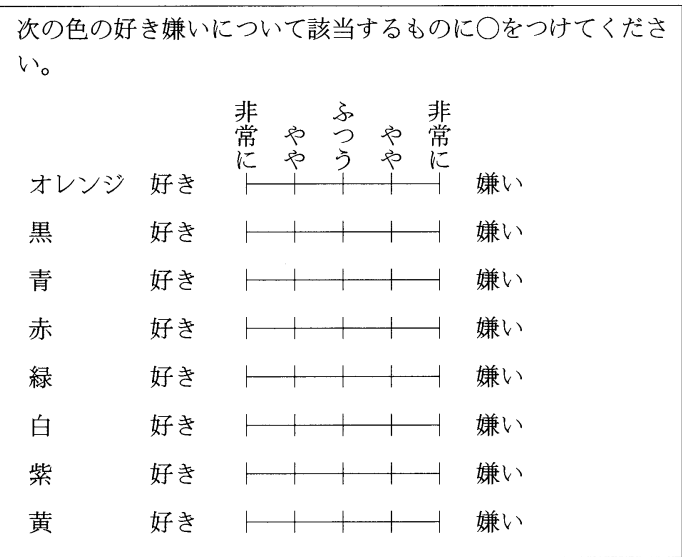

また，食卓の色彩の評価にパネリスト各自の色彩の好 みがどのように影響しているかをみるために，使用した 8 色彩の印象について「非常に嫌い」〜「非常に好き」 の 5 段階で評価してもらった（表 3 ）.

\section{3. 結果及び考察}

$\mathrm{SD}$ 法によって得た結果を食品別に得点の平均值を求 めたが，パン・牛乳・サラダの得点間には有意差が認め られなかったため，3 食品をなとめて平均值を求め, 図 2 に示した. 直接食欲に関わる形容詞 4 対を上側に, 直 接食欲には関わらない形容詞 6 対を下側に図示してあ る. 全般に，上位に位置付けられる色彩あるいは下位に
位置付けられる色彩は，ほぼ一定しており，上位に位置 する色彩は，オレンジ・青・白，下位に位置する色彩は 紫・緑・黒であった. オレンジの評価が高いという結果 は，F.Birrenの壁紙の調査結果と一致している.

各色彩間の平均值を有意差検定した結果, 食卓の色が オレンジのときの食物の印象については「好き」「おい しそう」「栄養がありそうな」と評価され，他の色彩に 比べて有意に高い評価となった，また，食卓の色が緑・ 紫・黒のときの食物の評価は有意に低く，特に紫の場合 は「田舎っぽい」「年よりじみた」「不潔な」「栄養がな さそうな」「下品な」「美しくない」と評価され，他の色 彩よりも有意に低い評価となった.

次に10項目全てのデータを集計し, 各食卓の色彩間の 有意差検定を行った結果が表 4 である. 紫一黄間に $1 \%$ の危険率, 紫一オレンジ及び紫一赤間には $5 \%$ の危険率 で有意差が認められたが，他の食卓の色彩間には差が認

表 4 色彩間の有意差検定

\begin{tabular}{c|c|c|c|c|c|c|c|c}
\hline & 黄 & オレンシ & 赤 & 紫 & 青 & 緑 & 白 & 黑 \\
\hline 黄 & & & & $* * *$ & & & & \\
オレンシ & & & & $* *$ & & & & \\
赤 & & & & $* *$ & & & & \\
紫 & & & & & $*$ & & $*$ & \\
青 & & & & & & & & \\
緑 & & & & & & & \\
白 & & & & & & & \\
黑 & & & & & & \\
\hline$* * *$ & & & & & & & & \\
\hline
\end{tabular}

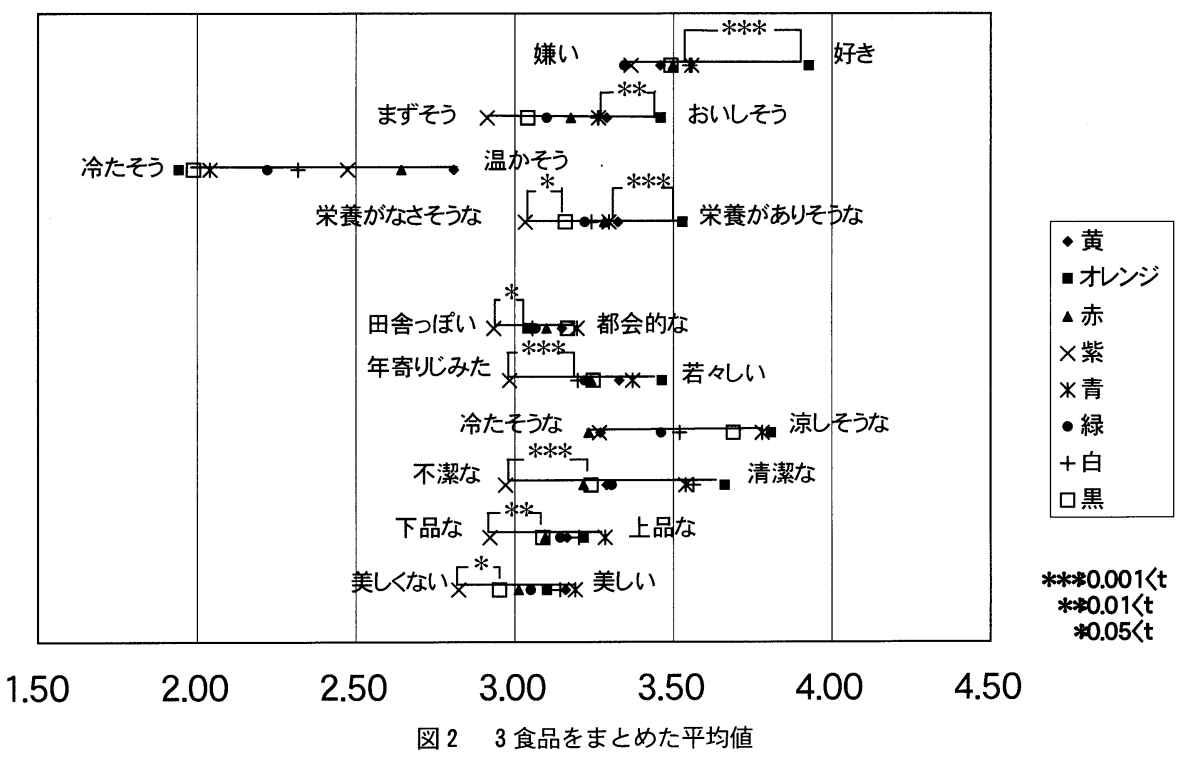

$174(20)$ 
められなかった．食卓の色彩が紫の場合の食物の評価は 全般に低い傾向にあり，一方オレンジの場合は好ましい 印象をもたれたが，他の食卓の各色彩間の差は小さかっ た。また，SD法で得られた10対の形容語対の得点をも とに因子分析を行い色彩別に検討をすすめた．表 5 にバ リマックス回転後の第一因子及び第二因子を示した.

第一因子については，白・青·緑・赤において「上品 な・下品な」「美しい.美しくない」の項目で因子負荷量 が大きくなっている. 黄·黒でも「美しい.美しくない」 の因子負荷量は大きい.これら6つの色彩では第一因子 は「優美さ」の因子であると解釈された．オレンジ・紫 においては他の色彩とは異なった項目の因子負荷量が高 く, オレンジは「都会的な・田舎っぽい」「清潔な・不潔 な」の項目で，紫は「清潔な・不潔な」「栄養がありそう な・なさそうな」の項目で因子負荷量が大きくなってい る。

第二因子については白·青·緑·赤・黒の 5 色彩におい て「都会的な・田舎っぽい」「若々しい·年よりじみた」 の項目での因子負荷量が大きく，これら5色彩について
の第二因子は「垢抜けている」の因子と解釈した。また， 黄·紫においては「好き·嫌い」「おいしそう・まずそう」 の項目で，オレンジでは「栄養がありそうな・なさそう な」の項目で因子負荷量が大きく，前出の 5 つの色彩と は異なった結果であった。

しかし，寄与率を見るといずれの色彩においてもあま り高いとはいえず，第二因子までの累積寄与率が $60 \%$ を 超えるものは黄のみ， $55 \%$ 以上は白·青·赤·黒の 4 色 彩に過ぎなかった。このことより食卓の色彩は, 色彩毎 に何らかのイメージを持つものの，そのイメージを明確 に意味付けすることはできなかった.

結果をまとめると，美味しそう・まずそうという印象 に及ぼす影響は，本研究のように食卓上にある食物・食 器の色彩が白・緑等単純な場合においては特徵的なこと は把握できなかった。

また SD 法の質問項目ごとにみれば「好きな色彩一嫌 いな色彩」「おいしそうに見える色彩一見えない色彩」 などを背景に，好ましい色彩から好ましくない色彩への 順位付けがなされた．この順位が純粋に食卓の印象によ

表 5 因子分析結果 第一因子,第二因子負荷量

第一因子

\begin{tabular}{|c|c|c|c|c|c|c|c|c|}
\hline & 白 & 黄 & オレンジ & 青 & 緑 & 紫 & 赤 & 黒 \\
\hline 好き・嫌い & 0.1972 & 0.2289 & 0.0345 & 0.2180 & 0.1961 & 0.1479 & 0.1439 & 0.1189 \\
\hline おいしそう・まずそう & 0.4395 & 0.5050 & 0.2832 & 0.3336 & 0.4176 & 0.5718 & 0.3787 & 0.4137 \\
\hline 温かそう・冷たそう & 0.1235 & 0.2704 & 0.1534 & 0.2363 & 0.0881 & 0.1338 & 0.0710 & 0.1742 \\
\hline 都会的な・田舎っぽい & 0.2160 & 0.3136 & 0.7742 & 0.1774 & 0.1457 & 0.5549 & 0.2233 & 0.0580 \\
\hline 若々しい・年寄りじみた & 0.2688 & 0.5183 & 0.4362 & 0.2783 & 0.3559 & 0.6232 & 0.2918 & 0.3235 \\
\hline 涼しそうな・暑苦しそうな & 0.1345 & 0.1653 & 0.2242 & 0.0943 & 0.1823 & 0.2642 & 0.1387 & 0.1835 \\
\hline 清潔な・不潔な & 0.5437 & 0.5698 & 0.6277 & 0.4746 & 0.6736 & 0.8737 & 0.7455 & 0.8081 \\
\hline 栄養がありそうな・なさそうな & 0.6667 & 0.8149 & 0.0711 & 0.2949 & 0.7097 & 0.8615 & 0.6074 & 0.6271 \\
\hline 上品な·下品な & 0.8592 & 0.7869 & 0.5909 & 0.8192 & 0.7782 & 0.6308 & 0.8356 & 0.6162 \\
\hline 美しい・美しくない & 0.7126 & 0.8972 & 0.5256 & 0.7400 & 0.7746 & 0.6175 & 0.9372 & 0.8049 \\
\hline 寄与率 (\%) & 47.8220 & 53.0425 & 34.4405 & 47.7122 & 25.6483 & 34.1758 & 43.0422 & 41.8235 \\
\hline
\end{tabular}

第二因子

\begin{tabular}{|c|c|c|c|c|c|c|c|c|}
\hline & 白 & 黄 & オレンジ & 青 & 緑 & 紫 & 赤 & 黒 \\
\hline 好き·嫌い & 0.2011 & 0.8702 & 0.0731 & 0.2185 & 0.1744 & 0.8563 & 0.2744 & -0.0073 \\
\hline おいしそう・まずそう & 0.1902 & 0.7318 & 0.4978 & 0.2865 & 0.3175 & 0.5664 & 0.3001 & 0.2005 \\
\hline 温かそう・冷たそう & 0.2315 & 0.1467 & 0.0995 & 0.2359 & 0.2513 & 0.1315 & 0.1953 & 0.2492 \\
\hline 都会的な・田舎っぽい & 0.6956 & 0.2123 & 0.0286 & 0.8311 & 0.9267 & 0.2237 & 0.9369 & 0.7893 \\
\hline 若々しい・年奇りじみた & 0.7358 & 0.2071 & 0.2629 & 0.8166 & 0.7928 & 0.1566 & 0.6845 & 0.8149 \\
\hline 涼しそうな・暑苦しそうな & 0.2264 & 0.0174 & 0.1548 & 0.1317 & 0.1322 & 0.1814 & 0.0369 & 0.1354 \\
\hline ·不潔な & 0.3777 & 0.3343 & 0.2708 & 0.2018 & 0.2222 & 0.1937 & 0.1964 & 0.1587 \\
\hline 栄養がありそうな・なさそうな & 0.0500 & 0.2285 & 0.7114 & 0.0747 & 0.0491 & 0.1735 & 0.0867 & 0.0475 \\
\hline 上品な・下品な & 0.3914 & 0.2800 & 0.4693 & 0.3000 & 0.4250 & 0.2272 & 0.2104 & 0.5507 \\
\hline 美しい・美しく & 0.4758 & 0.2549 & 0.6061 & 0.3249 & 0.3100 & 0.2053 & 0.1903 & 0.4085 \\
\hline 寄与率 (\%) & 10.6628 & 12.4840 & 14.5794 & 11.4108 & 20.2774 & 13.4014 & 16.4040 & 12.7927 \\
\hline 累積寄与率 (\%) & 58.4848 & 65.5265 & 49.0198 & 59.1229 & 45.9257 & 47.5772 & 59.4462 & 54.6162 \\
\hline
\end{tabular}




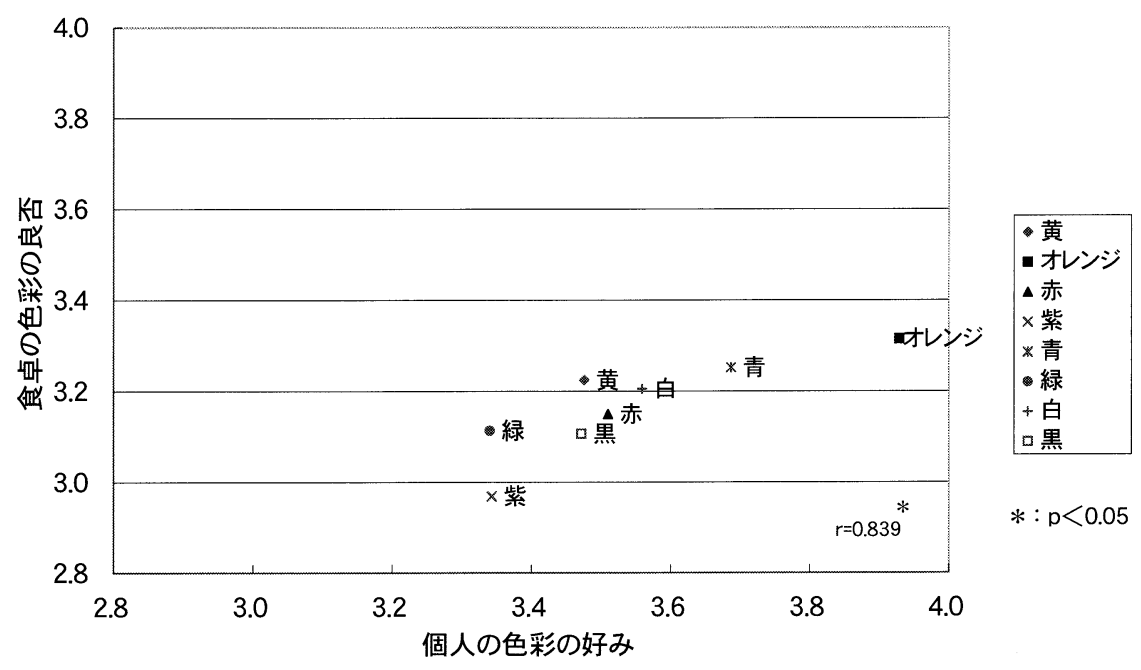

図 3 個人の色彩の好みと食卓の色彩の良否の関係

って決定されたのか，あるいは個人の色彩の好みによっ て左右されたのかを知るために，個人の色彩の好みにつ いて質問した，個人の色彩の好みの平均值を縦軸に，食 卓の評価の平均值を横軸に図 3 を作成した。相関係数を 算出したところ 0.839 と高く, 両者間には有意な相関が 認められた．評価の高かったオレンジについては，個人 の色彩の好みで「好き」「やや好き」という回答が約 37 $\%$ ，「嫌い」「やや嫌い」が約 $8 \%$ であり，食卓の評価は 「非常に・やや」を合わせた肯定の評価が約 $30 \%$, 否定 の評価が約 $10 \%$ であった。

このことより, 食卓の印象は, 食物がどのようなイメー シとしてとらえられるかよりは，個人の色彩の好みのほ うが大きく影響することが示唆された.

\section{4. 要約}

食卓の色彩が食物の印象にどの程度影響するのかを検 討するために, 食卓上に牛乳・パン・卵・サラダを配膳 し食卓を黄·オレンジ・赤・紫·青·緑・白·黒の各色 彩に変え，10対の形容語による SD 法によって官能評価 を行った.

(1) 食物の背景を構成する食卓の色彩の違いに対する 評価は，オレンジが「好き」「おいしそう」「栄養があり そうな」と評価され，紫は「田舎っぽい」「年よりじみ た」「不潔な」「栄養がなさそうな」「下品な」「美しくな い」と評価される傾向にある.色彩間の差については, オレンジ・紫以外の他の色彩間には差が認められなかっ た. 本研究のように食卓上の食物・食器の色彩が白・緑
等単純な場合においてはおいしさに及ぼす影響はあまり 大きいものではないと考えられた.

(2) SD法において得られた結果を因子分析したが， いずれの色彩においても累積寄与率が小さく, 傾向がつ かめなかった。

(3) 食物の背景を構成する食卓の色彩の違いに対する 評価は, 個人の色彩の好みと有意に相関が認められ, 個 人の色彩の好みに左右されるところが大きいと考えられ た。

\section{文献}

1) 柳本正勝: 日本調理科学学会誌, vol. 35, 32 36 (2002)

2）奥田弘枝, 田坂美央, 由井明子, 川染節江 : 日本調理科学 学会誌, vol. 35, 2 9 (2002)

3）江角有希子, 小原郁夫：日本家政学会誌, vol. 52, 597〜 604 (2001)

4）森重敏子, 青山よしの, 堀 洋子, 金子小千枝 : 日本調理 科学学会誌, vol. 19, 306 312 (1986)

5）森重敏子, 青山よしの, 堀 洋子, 金子小千枝 : 日本調理 科学学会誌, vol. 17, 253 258 (1984)

6) 森重敏子, 青山よしの, 堀 洋子, 金子小千枝 : 日本調理 科学学会誌, vol. 14, 247 252 (1981)

7）今井弥生, 津久井亜紀夫, 西川真理枝, 高野美栄 : 第32回 日本家政学会報文集，23～29（1980）

8）川染節江 : 明善短期大学研究紀要, vol. 13, 18 26 (1982)

9）川染節江：明善短期大学研究紀要, vol. 17, 42 49 (1986)

10）川染節江：日本家政学会誌, vol. 38, 23～31（1987）

11）岡本純代, 天野幸子：生活学論叢 3 号（1998）

12) F. Birren : Food Technology, 17, 553 (1963)

13）大谷貴美子, 饗庭照美, 徳田涼子, 尾崎彩子, 南出隆久： 日本調理科学学会誌, vol. 34, 270 275（2001）

14）日本色彩研究所 : 標準色彩図票 $\mathrm{A}$ 